\title{
ADAPTIVE MARKET? A NEW HYPOTHESIS?
}

\author{
Bayu Laksma Pradana \\ Sekolah Tinggi Ilmu Ekonomi Wiyatamandala \\ bayu.laksma@wiyatamandala.ac.id
}

\begin{abstract}
The efficient market hypothesis (EMH) has been challenged by behaviourists for decades. Is market predictable? and how rational human beings prone to make flaws in making decisions are two general questions that still debatable until nowadays. A long argument between Rationalists and Behaviorists. A new theory emerged to find a way out and became the "middle way". It gave justifications that those previous theories have both their own strengths and also weakneses. Combining biology, neuro science, and evolution, The MIT Professor seemed to believe that finance and market today are more like evolutionary biology than physic. From time to time market adapts with environment, change in circumstances lead to change in behavior and methodology; this is what Andrew Lo called Adaptive Market. This literature study briefly explains the very start evidence about Efficient Market Hypothesis and how behaviour finance becomes the opponent of EMH. How adaptive market expands the horizon of interdiciplinary studies also will be presented in thorough manner. In conclusion, the new theory gives many proves that market is adaptive. However in contrast with behavior finance, adaptive market has more comprehensive reasons explaining the financial and economic environment that has been changed recently.
\end{abstract}

Keyword: Efficient Market Hypothesis, Adaptive Market, Behavioral Economics

\section{PENDAHULUAN}

Pada 28 Januari 1986, Pesawat ruang angkasa Challenger kebanggaan Amerika hancur berkeping-keping tak berbekas 73 detik setelah lepas landas. Komisi Keselamatan penerbangan Amerika menduga berbagai penyebab permasalahan tersebut. Pada Juni 1986, berita resmi dikeluarkan yang menyatakan bahwa kesalahan ada ada pada $O$-ring Seals yang gagal untuk menyesuaikan suhu 
pada kondisi lepas landas. Kejadian Challenger selain menjadi tragedi nasional juga menimbulkan gejolak keuangan khususnya pasar modal. Beberapa perusahaan penyedia suku cadang Challenger (Lockheed, Martin Marietta, Morton Thiokol, dan Rockwell International), tanpa menunggu pengumuman dari komisi kecelakaan pesawat, 4 saham tersebut mulai menunjukan penurunan 13 menit sejak challenger meledak. Morton Thiokol adalah pihak yang paling dirugikan, Saham Morton Thiokol turun $12 \%$ dihari tersebut, sampai pihak SEC harus melakukan penundaan perdagangan. Mengacu pada penelitian yang dilakukan oleh Maloney dan Mulherin (2003) pasar bereaksi terhadap informasi yang ada sangat cepat (wisdom of the crowd) mendahului para ahli yang melakukan investigasi. Dugaan adanya insider dari pihak Martin thiokol tidak ditemukan pada penelitian Maloney dan Mulherin (2003). Apa yang terjadi pada dapat menggambarkan bagaimana efficient market bekerja Grafik I menggambarkan penurunan harga yang terjadi beberapa jam setelah kejadian terjadi. Harga aset saham Martin Thiokol digerakan oleh informasi yang beredar di pasar. Terlepas dari informasi tersebut benar ataupun salah, pengaruhnya tetap besar pada harga asalkan investor percaya dan mengambil keputusan berdasarkannya.

\section{PEMBAHASAN}

\section{Efficient Market Hypothesis}

Di dalam Efficient market (Pasar Effisien) seluruh informasi tersedia dapat tercermin pada harga aset tersebut. Ini berarti dapat berarti bahwa sebuah harga aset dipasar telah mencerminkan harga sewajarnya. Jika nilai tersebut adalah wajar (fair value) maka aset tersebut tidak dapat dikatakan under value ataupun over value. Metode valuasi pada aset sering digunakan untuk menentukan kelayakan apakah sebuah aset menguntungkan untuk dimiliki ataupun tidak. Aset yang dibeli diberi label undervalue karena terdapat selisih perbedaan antara harga pasar aset saat ini dengan hasil valuasi aset. Valuasi aset menggunakan metode yang beragam dan informasi baik dari masa lalu ataupun masa mendatang. Dalam 
pasar yang efisien, selisih yang melibatkan selisih antara harga pasar aset dan harga penilaian aset dibawah harga pasar (under value) tidak akan dapat terjadi. Informasi yang tersebar cepat dan sempurna, tidak memungkinkan seorang investor pun untuk mengambil keuntungan dari kepemilikan informasi lebih dulu.

"Pasar yang tidak dapat terprediksi" diperkuat oleh malkiel (1999) dalam "Random walk Hypothesis" yang ia kemukakan dalam bukunya Random Walk Down Wallstreet (1973)". Random walk atau jalan acak menyatakan bahwa pasar modal yang terwakili dengan pasar saham tidak dapat diprediksi pola pergerakan harganya seperti layaknya langkah seorang mabuk. Langkah seorang mabuk (drunkard walks) diobservasi pertamakali oleh seorang ahli matematika perancis Jean Baptise Alfonso Bachalier (1870 - 1946) dimana ia melihat pola acak pada pasar saham di Paris. Hal ini dapat dinyatakan oleh harga yang dipengaruhi oleh informasi, dan karena informasi masa depan tidak dapat diprediksi maka pasar bergerak acak. Malkiel juga menyatakan bahwa seorang investor harus berani mempertimbangkan dan menerima risiko lebih tinggi jika ingin mendapatkan return lebih tinggi dibanding return pasar. Penelitian Random walk di pasar modal memberikan kontribusi pada cara berinvestasi, yaitu buy and hold atau passive trading strategy, bahwa tidak perlu lagi untuk membuat kalkulasi menentukan bagaimana saham akan bergerak dimasa depan, berinvestasi saja mengikuti pergerakan pasar.

Sejarah Efficient Market Hypothesis bermula dari Argumen Bachelier mengenai random walk theory, walaupun hal ini tidak terlalu populer sampai tahun 1954 ketika Paul A. Samuelson memecahkan perilaku harga pada future market. Samuelson melihat bahwa informasi yang menjadi faktor penentu harga aset terlihat memiliki pola-pola tertentu, namun pasar tetap bergerak secara acak. Alasannya adalah seluruh polapola pergerakan informasi masa lalu tersebut sudah terserap semua pada harga saat ini (current price). Oleh sebab itu, tidak mungkin bagi investor untuk memprediksi harga memakai informasi tersebut. 
Informasi tetap saja tidak terprediksi dan harga tetap acak.

"An "efficient" market is defined as a market where there are large numbers of rational, profitmaximizers actively competing, with each trying to predict future market values of individual securities, and where important current information is almost freely available to all participants... In an efficient market, on the average, competition will cause the full effects of new information on intrinsic values to be reflected "instaneously" in actual prices".

-Fama (1965)-

Pernyataan ini memperlihatkan hal penting bagi perkembangan Efficient Market Hypothesis. Catatan pertama adalah adanya kata "rational "yang dikemukakan oleh Fama memperlihatkan asumsi bahwa investor adalah seorang homo ekonomikus, dimana pelaku ekonomi membuat keputusan dengan telah mempertimbangkan seluruh opsi yang terbaik yang akan memuaskan utilitasnya. Pertimbanganya tersebut berlaku konstan dalam segala situasi sehingga bisa disimpulkan dari pernyataan diatas bahwa memaksimumkan profit menjadi motif utama. Catatan yang kedua adalah dalam persaingan sempurna informasi tersedia secara cumaCuma didalam pasar dan seluruh pelaku dapat mengaksesnya dengan mudah. Catatan yang terakhir adalah nilai intrinsik telah mencerminkan harga aktual.

Sumbangan Fama yang paling berharga adalah pembagian Efficient Market menjadi tiga bentuk, menurut informasinya. Weak, Semi strong dan strong, ketiganya merupakan bentuk dari pasar modal menurut derajat informasi yang ada. Bentuk lemah, menyatakan bahwa informasi masa lalu tidak dapat dijadikan prediksi masa depan. Dalam semi strong, informasi mengenai perusahaan seperti book to market ratio, sales, company earning dan lain-lain tidak berguna dalam memprediksi. Bentuk terakhir, bahkan informasi yang bersifat privat pun tidak dapat memprediksi. Observasi Fama pada saat itu memberikan petunjuk bahwa tidak ada gunanya melakukan analisa teknikal ataupun menyewa manajer investasi. 
Sumbangan terbesar dari Efficient

Market Hypothesis adalah metode investasi Buy and Hold. Dalam jangka panjang nilai pasar akan meningkat sehingga perdagangan secara aktif tidak perlu dilakukan. Selain itu EMH memberikan model teori bagaimana informasi mempengaruhi aset dan pasar.

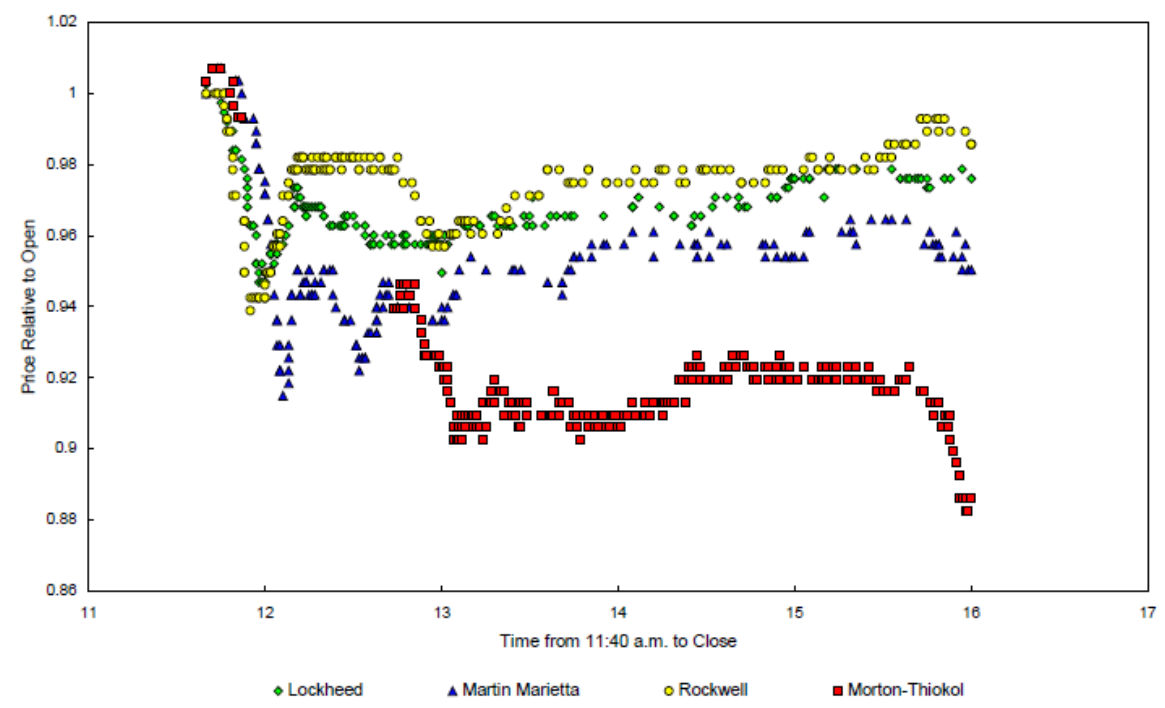

Gambar 1. Grafik Harga Martin Thiokol dan beberapa perusahaan lain

\section{Behavior Finance}

Tahun 2008 merupakan tahun kejatuhan finansial Amerika Serikat terburuk sejak tahun 1940 (The great Depression). Dimulai dengan housing bubles dan pengucuran kredit perumahan (mortgage loan) kepada masyarakat dan berakhir ketidak mampuan mereka untuk membayar menjadi dalang krisis ini. Instrumen keuangan yang semakin kompleks seperti mortgage backed securities, collateral debt obligation dan credit swap semakin menambah leverage yang pada instrumen kredit perumahan ini. Terjadinya excess of demand di pasar perumahan mengakibatkan bank melonggarkan persyaratan kredit untuk memenuhi permintaan tersebut. Walaupun terdokumentasi beberapa kali dalam sejarah Amerika bahwa kenaikan harga yang tinggi dan cepat sering diiringi dengan penurunan yang dalam namun para investor ataupun pelaku investasi gagal mendeteksi arah harga tersebut. Setelah kejatuhan harga rumah karena 
kegagalan pembayaran dari kreditur, harga rumah seperti terseret semakin dalam dan memberikan tekanan terhadap institusi perbankan, dan investasi. Aset rumah yang lambat bahkan tidak likuid menjadikan seluruh institusi yang terlibat, bangkrut.

Kejadian ini memberikan dampak pada kajian Efficient Markfet Hypothesis. Ada yang beranggapan bahwa Efficient market hypothesis gagal untuk menjelaskan bagaimana bubles dapat terjadi. Di tahun 2005 Robert shriller memperingatkan adanya gejala bubles pada sektor perumahan di Amerika. Dalam bukunya pula Shriller menjelaskan beberapa faktor yang memicu adanya irrational exuberance. Menurut shriller (2000) irrational exuberance kata yang dipopulerkan oleh Alan Greenspan mengacu pada keadaan sebuah pasar yang memuncak tanpa fundamental yang kuat dan tergerak oleh faktor psikologi pasar dan sangat berpotensi untuk turun secara drastis. Faktor psikologi dan emosi disinyalir adalah faktor yang menjelaskan bahwa pasar harus diobservasi bukan hanya dari sisi rasional tapi juga perilaku. Beberapa kajian intradisiplin antara psikologi dan ekonomi memunculkan wawasan teori baru yaitu Behavioural Economics atau Behavioural Finance. Para Behaviourist percaya bahwa didalam pasar yang berisi investor yang melakukan pembuatan keputusan baik pembelian atau penjualan saham sering kali bias dalam keputusannya. Behavior finance dan efficient market hypothesis merupakan dua hal yang mempengaruhi adanya bangunan teori baru, Adaptive Market.

Penelitian Efficient Market selalu bersandar pada asumsi " rational human being" bahwa setiap orang dalam membuat keputusan akan menggunakan kemampuan kognitifnya untuk membuat pilihan berdasarkan analisa yang menyeluruh dan terbaik, menggunakan proses pemikiran yang mendalam (deep thinking). Selanjutnya dari proses tersebut ia akan memilih pilihan yang mempunyai utilitas tertinggi bagi dirinya.

Peraih Nobel, Kahneman bersama Tversky menyusun sebuah teori perilaku yang dinamakan Prospect theory. Teori ini merupakan teori 
ekonomi keperilakuan yang

Kebanyakan orang akan menolak menjelaskan bagaimana seorang individu membuat keputusan yang melibatkan probabilitas (kemungkinan) dan pilihan, dimana didalam pilihan tersebut dimasukan faktor risiko ataupun kemungkinan hasil yang berbeda-beda. Jika seseorang ditawarkan untuk melempar sebuah koin yang terdiri dari 2 sisi, yaitu ekor (tail) dan kepala(head):

- Jika terlihat tail anda kalah \$ 100

tantangan ini dengan alasan bahwa mereka tidak ingin mengalami kerugian \$100. Walaupun jelas bahwa nilai ekspektasi tawaran ini adalah positif. Namun orang memberikan bobot kerugian lebih besar daripada bobotnya terhadap kemenangan. Kahneman (2009) menyebutnya "loses loom larger than gain" atau loss aversion. Didalam investasi loss aversion sering menjadi kendala ketika menilai sebuah investasi. Ketakutan

- Jika terlihat head anda menang \$ 150 mengenai risiko investasi lebih besar daripada potensi keuntungannya.

Apakah tantangan ini menarik?

Apakah anda akan menerimanya?

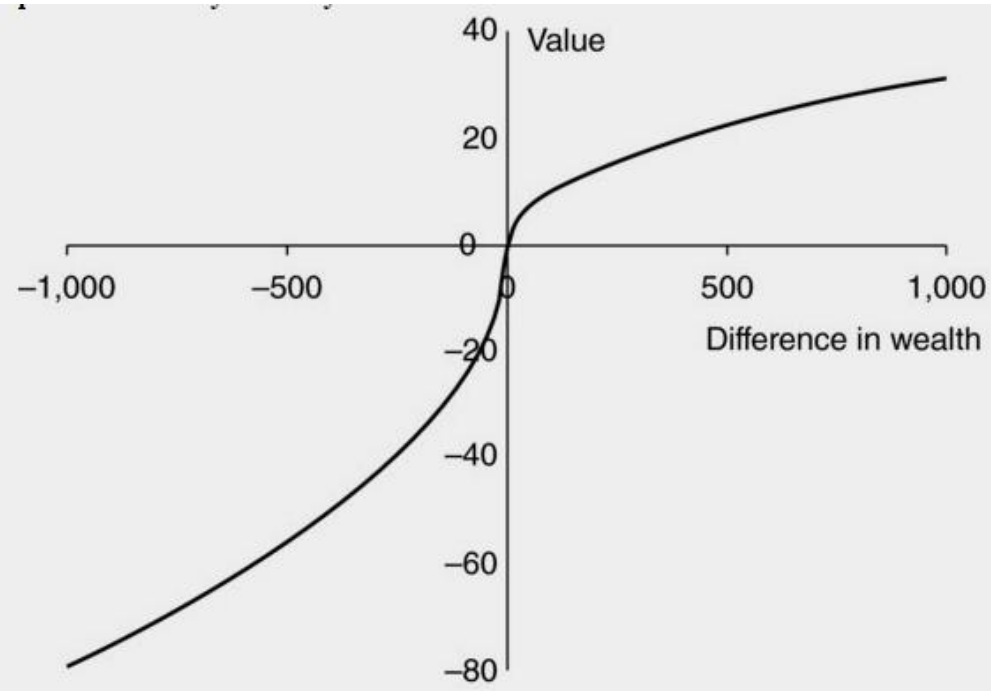

Grafik 2. Prospect theory / loss aversion 
Bounded Rationality juga merupakan kendala dari asumsi rasional pelaku ekonomi. Seseorang yang rasional akan memaksimumkan pilihan yang ada, pilihan yang optimum choice namun untuk memilih pilihan yang mendapatkan utilitas paling maksimum sangat terkendala oleh informasi, keterbatasan kognitif dan waktu yang dimiliki. Argumen Simon H. adalah bahwa seseorang cenderung lebih melakukan satisfice dibandingkan dengan optimize. Satisfice adalah keadaan mental yang terpuaskan dengan opsi-opsi yang ada. Dapat terjadi dalam proses satisfice bahwa opsi yang paling optimum tidak terjadi.

Dalam membuat keputusan, pelaku ekonomi seringkali bergantung dengan bagaimana sebuah informasi disampaikan. Kahneman dan Tversky (1979) melakukan penelitian framing effect dengan melakukan eksperimen sebagai berikut:

Jika pada suatu daerah terdapat sebuah wabah penyakit yang dimungkinkan akan membunuh 600 orang. Terdapat dua alternatif pilihan eksperimen yang bisa digunakan untuk menanggulangi wabah ini:

Eksperimen 1
- Jika alternatif A digunakan maka 200 orang akan dapat diselamatkan

- Jika alternatif B digunakan maka kemungkinan yang ada adalah 1/3 kemungkinan bahwa 600 orang akan selamat dan 2/3 kemungkinan bahwa sisanya tidak akan selamat.

Manakah dari dua program ini yang akan anda jalankan?

Eksperimen 2

Pada kelompok kedua pilihan yang digunakan adalah sebagai berikut:

- Jika alternatif $\mathrm{C}$ digunakan maka 400 orang tidak dapat diselamatkan

- Jika alternatif B digunakan maka kemungkinan yang ada adalah 1/3 kemungkinan bahwa tidak akan ada yang mati dan 2/3 kemungkinan bahwa sisanya tidak akan selamat.

Manakah dari dua program ini yang akan anda jalankan?

Pada eksperimen 1 kebanyakan orang memilih opsi A sedangkan pada eksperimen 2 pada B. Dalam teori keuangan perilaku ketika sebuah masalah dipresentasikan 
dengan menonjolkan keuntungan (gain) maka sebagian orang akan menjadi risk averse. Kebalikannya jika cara mempresentasikannya adalah dengan kerugian (losses) maka sebagian orang menjadi risk taker. Secara perhitungan keuangan tradisional maka seseorang akan secara konsisten memilih A dan C ketika mereka adalah seseorang risk averse dan memilih $\mathrm{B}$ dan $\mathrm{D}$ ketika mereka risk taker.

Terdapatnya bounded rationality menyebabkan sebuah masalah dapat menjadi sangat kompleks. Kompleksitas ini mengarahkan setiap pelaku ekonomi untuk menggunakan heuristic atau rules of thumb untuk memecahkan masalah. Heuristic adalah cara-cara sederhana untuk menyelesaikan masalah. Misalnya, seseorang yang akan memilih berbagai pilihan saham, cenderung untuk memilih saham yang sudah diketahuinya atau ia berpikir ia mengetahui seluk beluk saham tersebut.

Overconfidence merupakan kecenderungan orang untuk terlalu percaya diri terhadap kemampuan, keahlian dan pengetahuannya. Didalam pasar efek bias ini sangatlah berpengaruh, (Barber dan Odean 2000) melakukan penelitian dan memakai trading intensity beserta gender sebagai proxy overconvidence. Semakin banyak trading dilakukan (exescive trading) berarti seseorang mempunyai kecenderungan untuk overconfident. Disposition effect merupakan kecenderungan untuk menahan kerugian terlalu lama namun melakukan eksekusi keuntungan terlalu cepat. Emosi adalah salah satu yang memainkan peranan dalam disposition effect ini.

Beberapa bias ini menekankan pada aspek perilaku dalam dunia keuangan. Behavioral finance berusaha menjelaskan bahwa pasar tidak selalu efisien dan manusia yang terlibat didalamnya pun sering kali tidak rasional. Hal ini bertentangan dengan Efficient Market Hypothesis yang menyandarkan teorinya pada paradigma tradisional keuangan manusia "rasional".

\section{Adaptive Market}

From the adaptive market point of view, the efficient market hypothesis isn't wrong but incomplete.

Andrew Lo (2018) 
Adaptive market hypothesis (AMH) di kemukakan oleh seorang Profesor MIT Andrew Lo. Teori ini merupakan jalan tengah bagi perang teori dari sisi pendukung Efficient Market Hypothesis dan Behaviorist Theory. Efficient Market hypothesis merupakan teori yang cukup kuat dan bertahan selama beberapa dekade. Sedangkan para behaviorist menurut Andrew Lo (2017) belum menemukan bangunan teori yang cukup kokoh. Mencoba mencari teori baru " it takes a theory to beat a theory" maka Adaptive maket hypothesis muncul dengan tidak hanya menggabungkan dua teori tersebut namun juga melakukan studi interdisiplin ke arah evolusi, biologi dan neuro science. Andrew Lo (2017) menyatakan bahwa teori ini memberikan wawasan bahwa investor dan pasar keuangan berperilaku lebih menyerupai hukum biologi daripada hukum fisika, layaknya biologi yang terdiri dari populasi organisme-organisme hidup berusaha untuk bertahan hidup (survival), bukan sekumpulan benda mati (mundane) yang mengikuti hukum gerak ( law of motion).
Kritik terbesar adaptive market juga terdapat pada pernyataan ekonomi “ Rational Economic Man" yang menjadi dasar bagi Efficient Market Hypothesis. Serupa dengan pernyataan behaviour science bahwa EMH dalam perkembangannya telah melupakan aspek perilaku manusia dan menyandarkan dirinya pada matematis. Lebih jauh lagi adaptive market hypothesis melihat bahwa manusia tidak selalu rasional dan tidak selalu irrasional. Pilihannya untuk bertindak seutuhnya adalah tergantung oleh keadaan pada saat itu. Seluruh ketergantungannya tersebut berdasar pada kebutuhannya akan survival. Prinsip ini merupakan prinsip dari evolusi dimana secara biologi, untuk bertahan hidup secara jangka panjang akan terdapat perubahan pada struktur tubuh suatu organisme.

Herding behavior atau perilaku kerumunan dapat menjelaskan bagaimana di tahun 2008 wisdom of crowd berubah menjadi madness of mob. Panik karena ketakutan membuat perilaku herding terjadi, kebanyakan investor yang mempunyai asumsi utilitas konstan berubah irrasional sehingga 
mempercepat jatuhnya ekonomi amerika. Tergantung dari lingkungannya manusia yang konstan rasional karena dipenuhi rasa panik (hasil evolusi biologi ) mencoba bertahan hidup untuk menyelamatkan posisi keuangannya.

Urguhart dan Mcgroarty (2014) dalam penelitiannya mengenai anomali menyatakan bahwa Adaptive market hypothesis lebih dapat menjelaskan eksistensi kinerja anomali kalender dalam variasi waktu yang berbeda-beda dibandingkan dengan efficiency market hypothesis. Lebih jauh lagi ia menyatakan di tahun 2016 return predictability juga berbeda-beda setiap saat. Temuan ini konsisten karena setiap pasar beradaptasi terhadap kondisi pasar.

Noda (2015) juga mendukung AMH pada pasar modal di Jepang. Ia melakukan pengujian tingkat efisiensi pasar menggunakan pendekatan time varying model. Hasil empirisnya menunjukan, bahwa dalam kurun waktu tertentu efisiensi pasar berbeda di dua pasar. (Amelie, Darne, \& Kim, 2017), menemukan bahwa Indeks saham islami dan indeks konvensional tingkat pengembaliannya terprediksi dalam beberapa periode, sehingga hal ini konsisten dengan teori AMH. Hal ini adalah hasil studi empirisnya pada Dow Jones Islamic selama 1996 sampai 2003.

(Lo, 2017) menyatakan beberapa prinsip berkenaan dengan Adaptive Market Hypothesis

1. Manusia tidak selalu rasional maupun irasional. Manusia adalah entitas biologis yang memiliki atribut-atribut serta perilaku tertentu yang dibentuk oleh proses evolusi.

2. Manusia memiliki bias perilaku dan membuat keputusan yang suboptimal, namun kita dapat pelajaran dari pengalaman masa lalu dan dapat memperbaiki heuristic yang dimiliki sebagai respon dari umpan balik negatif.

3. Manusia memiliki kemampuan untuk berpikir abstrak, mampu melakukan analisis, melakukan prediksi berdasarkan pengalaman masa lalu, persiapan untuk perubahan pada lingkungan saat ini. Evolusi secepat 
pikiran, yang berbeda namun berhubungan dengan evolusi biologi.

4. Dinamika pasar keuangan diarahkan oleh interaksiinteraksi yang sejalan dengan bagaimana kita berperilaku, belajar dan beradaptasi. Adaptasi ini terjadi dari kita ke sosial, budaya, politik, ekonomi dan lingkungan tempat kita bernaung.

5. Survival adalah faktor utama yang mengarahkan kompetisi, inovasi dan adaptasi.

\section{KESIMPULAN}

Efficient market hypothesis merupakan teori yang sangat kuat dalam menjelaskan berbagai fenomena ekonomi dan keuangan sejak pertama kali diperkenalkan. Walaupun teori ini dianggap telah gagal dalam menjelaskan beberapa fenomena pasar ( anomali) ataupun kejadian krisis global yang lebih sistemik, namun beberapa teori yang mendasarkan pada Efficient Market Hypothesis juga telah mampu menyumbangkan teori besar lain.

Salah satu yang tidak dapat dipungkiri oleh asumsi dasar dari
EMH adalah manusia selalu bertindak rasional. Bantahan keras dari para pelaku behavior finance sangatlah beralasan mengingat manusia secara naluri telah memiliki pemikiran irasional yang berasal dari keterikatannya pada emosi.

Teori Adaptive Market merupakan teori yang sangat fleksible dan dapat menggantikan dan menjadi jalan tengah dari kedua teori diatas. Tidak selamanya sebuah teori dapat menjelaskan fenomena yang terjadi dimana lingkungan yang ada saat ini menjadi sangat kompleks. Maraknya hedgefund, financial technology (fintech), Robotic investment, crypto currency ataupun instrumen berbasis derivatif lainnya membuat financial economics, menjadi dinamis dan tidak menentu. Hal ini mengakibatkan pola perilaku yang berubah pula mengikuti insting bertahan hidup, sehingga model ekonomi juga harus dapat dipertimbangkan untuk dapat berevolusi sesuai perkembangan lingkungan.

Adaptive market dapat lebih dikembangkan menjadi lebih komprehensif sejalan dengan 
perkembangan dari interdisiplin yang mendukungnya.

\section{DAFTAR PUSTAKA}

Ackert, L. F., \& Deaves, R. (2009). Behavioral

Finance:

Psychology, Decision making and Market Independence. Cengage Learning.

Amelie, C., Darne, O., \& Kim, J. H. (2017). Adaptive Markets Hypothesis for Islamic Stock Indices: Evidence from Dow Jones Size and SectorIndices. International

Economics, 100-112.

fama, F. E. (1969, December).

Efficient Capital Markets : A review of Theory and Empirical Work. The Journal of Finance, 25(2), 28-30.

Kahneman, D., \& Tversky, A. (1979, March). Prospect Theory :An analysisy of Decision Under Risk. Econometrica, 263 291.

Lo, A. W. (2017). Adaptive Market. New Jersey: Princeton University Press.
Malkiel, B. G. (1999). A Random Walk Down Wall Street. Newyork: W.W. Norton \& Company, Inc.

Maloney, M. T., \& Mulherin, J. H. (2003). The Complexity of Price Discovery in an Efficient Market. Journal of Corporate finance.

Noda, A. (2015, January). A Test of The Adaptive Market Hypothesis Using a TimeVarying AR Model in Japan. Finance Research Letter, 6671.

Sewel, M. (2011, January 20). History of The Efficient Market Hypothesis. UCL Department of computer science.

Shiller, J. R. (2000). Irrational Exuberance. New Jersey: Princeton University Press.

Urquhart, A., \& McGroarty, F. (2014). Calender Effects, Market Condition, and The Adaptive Market Hypothesis: Evidence from Long-run US data. International Review of Financial Analysis, 154-166. 
Urquhart, A., \& McGroarty, F. (2016, July 6). Are Stock

Market Really Efficient?

Evidence from The Adaptive

Market Hypothesis.

International Review of

Financial Analysis, 39-49. 